\title{
DESIGN OF A ROBOTIC TOY AND USER INTERFACES FOR AUTISM SPECTRUM DISORDER RISK ASSESSMENT
}

\author{
Deniz UNCULAR \\ Sabanc1 University, Turkey \\ denizuncular@sabanciuniv.edu \\ Selçuk ARTUT \\ Sabanc1 University, Turkey \\ sartut@sabanciuniv.edu \\ https://orcid.org/0000-0001-7323-7234
}

\begin{abstract}
Autism Spectrum Disorder (ASD) is an umbrella term for a spectrum of complex developmental disorders resulting in deficits in social communication and repetitive and stereotyped behaviors (APA, 2013). According to research conducted in 2014, one in every 68 children in the United States is diagnosed with ASD (Baio, 2014). Despite this observation, it is observed that there is no national screening system in Turkey, and screenings are not conducted systematically (Rakap et al., 2017). Research in the area revealed that individuals with ASD are more interested in interacting with technology (e.g. computers, iPad, robots, etc.) than human beings (Fong et al., 2003). This paper includes research into how to design and use technology to create suitable products for deficits of ASD. With all the concern over the high prevalence ratios of ASD, this study presents the methodology and design of a risk assessment device, which aims to capture the interest of children with ASD aged 3-4, and direct children who score low on the tests towards a diagnosis. The tests in the device focus on Theory of Mind (ToM) development and designed to detect differences with ToM tests between ASD and Typically Developing (TD) children. In the scope of the paper, 2D illustrations, interface design, and outer shell design of the device are created in compliance with the research data in the field. Finally, outer shell design is 3D printed and surface finishing is completed.
\end{abstract}

Keywords: Autism spectrum disorder, Interface design, Product design, Risk assessment, Robotic toy, $2 D$ illustration, $3 D$ printing

\section{OTIZM SPEKTRUM BOZUKLUĞU RISSK DEĞERLENDİRMESINE YÖNELIK ROBOTIK OYUNCAK VE KULLANICI ARAYÜZÜ TASARIMI}

\section{ÖZ}

Otizm Spektrum Bozukluğu (OSB) hafiften şiddetliye kadar karmaşık gelişimsel bozukluklar için kullanılan yelpaze terimidir. Bu gelişimsel bozukluklar sosyal iletişimde yetersizlik, tekrarlayıcı ve sterotipik davranışlara neden olmaktadır (APA, 2013). 2014 yılında yapılan bir araştırmaya göre, Birleşik Devletler'de her 68 çocuktan biri OSB tanısı almaktadır (Baio, 2014). Bu gözleme rağmen, Türkiye'de ulusal tarama sistemi bulunmamaktadır ve taramaların sistemli yürütülmediği gözlemlenmektedir. (Rakap et al., 2017). Alandaki araştırmalar OSB'li bireylerin teknolojiyle (ör. bilgisayarlar, iPad, robotlar, vb.) etkileşime geçmekte insanlarla etkileşime geçmeye kıyasla daha istekli olduklarını ortaya çıkarmıştır (Fong et al., 2003). Bu çalışma OSB'nin yol açtığı eksikliklere uygun ürün yaratmak için tasarımın nasıl yapılması ve teknolojinin nasıl kullanılması gerektiği araştırmasını kapsamaktadır. OSB'nin yüksek yaygınlık oranları göz önüne alındığında, bu araştırma bir risk değerlendirme cihazının metodolojisini ve tasarımını sunmaktadır. Bu cihaz 3-4 yaş aralığındaki çocukların ilgisini çekmeyi ve testlerde düşük puan alan çocukları teşhise yönlendirmeyi hedeflemektedir. Cihazın içindeki testler özellikle Zihin Kuramı gelişimine odaklanmaktadır ve OSB'li çocuklarla tipik gelişim gösteren çocuklar arasındaki farklılıkları Zihin Kuramı testleriyle saptamaya 
yönelik tasarlanmıştır. Araştırma kapsamında cihazın prototipinin iki boyutlu illüstrasyonları, arayüz tasarımları ve dış kabuk tasarımı alandaki araştırma verilerine uygun olarak yapılmıştır. Son olarak, dış kabuk tasarımı 3 Boyutlu yazıcı ile basılıp yüzeyi rötuşlanmıştır.

\author{
Anahtar Kelimeler: Otizm spektrum bozukluğu, Ara-yüz tasarımı, Ürün tasarımı, Risk \\ değerlendirmesi, Robotik oyuncak, 2 boyutlu illüstrasyon, 3 boyutlu baskl
}

\title{
INTRODUCTION
}

According to the American Psychological Association (APA), Autism Spectrum Disorder (ASD) is an umbrella term for a spectrum of complex developmental disorders resulting in deficits in social communication and repetitive and stereotyped behaviors (APA, 2013). Individuals with Autism spectrum disorder (ASD) experience impairments in social communication and social interaction. These impairments include issues in social exchange, gestural behaviors in communication, and difficulties in building, preserving, and comprehending relationships. In addition to these impairments, behavior and interests appear to be limited and are marked by repetitive patterns (APA, 2013). Moreover, children with ASD suffer from impairments in communicating verbally and nonverbally, particularly with actions involving motor control, facial expression of emotions, and eye gaze attention (Dautenhahn, 2002). The diagnosis of ASD relies on behavioral criteria determined in a diagnostic handbook named the DSM-V (APA, 2013).

According to research conducted in 2014 (U.S.), one in every 68 children in the United States is diagnosed with ASD (Baio, 2014). According to research conducted by Autism Platform and their predictions from previous years, it is assumed that there are 550.000 children with ASD in Turkey and approximately 150.000 children with ASD aged between 0-14 years. Despite this observation, there is no national screening system in Turkey, and screenings are not conducted systematically. Also, despite the importance of early diagnosis, it is hard to say that early diagnosis has been achieved at a necessary level in Turkey (Rakap et al., 2017). Research into how to design and use technology that would increase diagnosis rates for ASD diagnosis is increasingly important. With all the concern over the high prevalence ratios of ASD, this study aims to make a prototype of a risk assessment device as a supplementary tool for supporting screening systems in Turkey.

Research in the area revealed that individuals with ASD are more interested in interacting with technology (e.g. computers, iPad, robots, etc.) than human beings (Fong et al., 2003). In accordance with this, in the last decade researchers have performed numerous studies that have used technology in therapy, diagnosis, and collecting data from the behavioral responses of individuals with ASD (FeilSeifer, 2005; Cabibihan, 2013). This study presents the methodology and design of a risk assessment device, which aims to capture the interest of children with ASD aged 3-4, and direct children who score low on the tests towards a diagnosis. The tests in the device focus on Theory of Mind (ToM) development and designed to detect differences with ToM tests between ASD and Typically Developing (TD) children.

\section{AUTISM SPECTRUM DISORDER IN INFANCY AND EARLY CHILDHOOD}

Abnormality of child's development is recognized by twenty-four months in $90 \%$ of the cases (De Giacomo \& Fombonne, 1998). Proper gestures such as nodding and pointing appear to be absent after one year. However, the early signs of Autism Spectrum Disorder (ASD) alter with age. Infants with ASD might exhibit restricted eye contact and reduced social attention (Maestro et al. 2002). Both motor and vocal imitation may be diminished, and they may have difficulties with arousing or possess abnormal physical reactions (Dawson et al. 2000). According to the study of Maestro et al. (2002), compared to age matched control groups, infants later diagnosed with ASD displayed weaker visual attention to social stimuli. They were also less frequent in smiling, vocalizing, and engaging in object exploration. Their repetitive behaviors, however, did not differ from the control group. The studies of Werner et al. (2000) and Osterling and Dawson (1994), with 8 to 10-month-old infants and 12 monthold infant participants respectively, reported that infants later diagnosed with ASD tend to respond to their names less. 
According to research in the area, the early predictors of ASD are as follows: diminished interest in social interaction, impaired social engagement, and communication difficulties starting from the first few months. However, other than social difficulties, dissimilarities from the control group are less prominent. Differences in communication such as the absence of attention toward speech, including their name, appear to be more noticeable by six to twelve months. Infants diagnosed with ASD in the future tend to have a reduced interest in social interaction with people and are less integrated in object exploration compared with typically developing infants (Bates et al. 1979). Social abnormality and communication deficits become prominent by thirty months (Ornitzet al. 1977). Children with ASD diverge from typical age matched children in terms of anticipatory postures, turn taking ability, eye contact level, and joint attention (Wimpory et al. 2000). They also exhibit atypical sensory behaviors and reduced emotional interaction (Hoshino et al. 1982). Below the age of three, children with ASD can be distinguished from typically developing or developmentally delayed children in terms of hindered social development, abnormal gaze, unusual play, and unresponsiveness to verbal communication (Dahlgren \& Gillberg, 1989). Early diagnosis and intervention is essential for enhanced long-term results, yet though initial indications of ASD are observable in numerous instances before 12 months of age, infants and young children are challenging to diagnose (Volkmar et al. 1994).

\section{THEORY OF MIND AND AUTISM SPECTRUM DISORDER}

Theory of "mind blindness" has been proposed as the cognitive reason for social and communication difficulties of Autism Spectrum Disorder (ASD). This theory presumes that typically developed individuals can "mind read", which means that they are able to understand their own mental state and other people's mental states; this is also called the "Theory of Mind" (ToM) and "mentalizing". However, individuals with ASD have difficulties in social communication and with perceiving mental states (Frith, 2001). Typically developing children's ability to mentalize is believed to start with an innate mechanism and to develop with the child's social environment (Frith, 2001). Early indications of interest regarding the mental states of other individuals are observed through shared attention (Carpenter et al., 1998). Infants in the first year of life instinctively track the gaze direction of another person, meaning they direct their attention to what another person is attending. Referential looking is also present, meaning infants examine their caregiver's emotional manner before getting near or holding back from a new object (Repacholi, 1998). Imitation of complicated and deliberate activities of other people start at 1.5 years of age (Meltzoff, 1995). Children around 2-3 years old acquire the ability to comprehend and practice mental state verbs such as want, know, and pretend (Bretherton, 1992). Mentalizing is believed to assist with learning word meanings (Bloom, 2000) by following the referential objective of the agent as well (Baldwin et al., 1996). Sophisticated matters such as false belief, deception, white lie, and double bluff are obtained frequently between 5-8 years of age (Frith, 2001).

The theory of mind hypothesis proposes that the innate mentalizing mechanism does not function properly in individuals with ASD. Although they may be able to learn mental states through training, they obtain this ability late and slow, also inclined to making mistakes when it comes to more complex mentalizing tasks, such as second- order false belief tasks (Frith, 2001). The mind blindness hypothesis does not imply that this is the underlying reason for repetitive behavior and the restricted, compulsively followed activities present in ASD, but it might be the reason for certain language deficits. Indeed, idiosyncratic use of language, language delay, muteness, and echoing of speech are common characteristics of ASD. Caregivers report abnormal ways of word learning even in children with Asperger disorder (Frith, 2001).

Having a Theory of Mind (ToM) requires being able to comprehend all types of mental states and being capable of reflecting on what is in one's own mind and the minds of others. In Autism Spectrum Disorder (ASD), the problem of comprehension regarding another person's mind is a fundamental 
cognitive characteristic and seems to be universal. To be able to reveal this condition, developmentally appropriate tests should be practiced (Baron-Cohen, 2001).

\section{BENEFITS OF IMPLEMENTATION OF TECHNOLOGICAL SYSTEMS FOR AUTISM SPECTRUM DISORDER}

Individuals with Autism Spectrum Disorder (ASD) and their families confront difficulties in acquiring health care. In Turkey, children diagnosed with ASD need to be assessed by "Guidance and Research Center (GARC)" (Rehberlik ve Araştırma Merkezleri) in order to access special education services provided by the state (Aksoy \& Diken, 2017). However, there are significant limitations concerning qualified and experienced special education personnel in ASD at GARCs. Personnel in these institutions have prior education in mind, hearing, or visual impairment and later receive limited education in ASD (Rakap et al., 2017). Another limitation is a lack of adequate assessment instruments and educated personnel who are able to practice proper evaluation regarding communication, social interaction, and restrictive patterns of behavior (Rakap et al., 2017). Educational assessment can only be conducted at GARCs, yet there are only one or two GARCs in the majority of provinces in Turkey. These circumstances result in families who live far from the city centers travelling great distances to access services. Complicating the picture more, since there are only one or two GARCs in the majority of provinces in Turkey, these institutions are over-occupied. This excessive workload results in hindering an extensive educational assessment process and impacting its quality. Furthermore, educational assessment and diagnosis conducted outside the natural environment of the child hinders the data gathering process about the natural behavior of the child (Rakap et al., 2017).

Autism spectrum disorder diagnosis rates in children have been increasing in recent years. A child is born with ASD one in every 68 births (Baio, 2014). However, according to a recent study conducted in Turkey by Tohum Otizm Vakf1, only $58 \%$ of the citizens answered yes to the question: "Have you ever heard of a developmental disorder by the name of autism?" and only $18 \%$ answered yes to the question "Are you aware of the symptoms of autism?" ("Türkiye'deki Bireylerin Otizm Algısı ve Bilgi Düzeyi Araştırması", 2017). Infrastructural drawbacks accompanied by low awareness rates lead to difficulties in diagnosis. Complementary implementation of technological systems may increase the awareness of citizens about ASD risk and early diagnosis.

Individuals with ASD are mainly attracted to and motivated by technology: therefore, technologyfacilitated education is suitable to assist them in concentrating on academic and behavioral development. Professional assistance in the area is expensive and may be unreachable for some caregivers. Technology-facilitated mobile instruments for education and self-management may be beneficial for improving skills of individuals with ASD and their caregivers, which may decrease their dependence on professional assistance (Goodwin, 2008). For example, wearable sensors that can detect and record sensory input enable the interpretation of the arousal levels of individuals with ASD, thus assisting them in comprehending, transferring, and controlling their arousal levels (Goodwin et al., 2006). A growing body of research has been conducted to evaluate the benefits of implementation of technological systems for ASD. A high proportion of the research in this area focuses on social interaction and communication difficulties (Grynszpan et al., 2008). Advantages of implementation of technological systems include adaptability, manageability, and supportiveness. Since individuals with ASD generally experience difficulties while interacting with other individuals, human-computer interaction appears to be more comfortable, attractive, and pleasant for children with ASD (Boucenna et al., 2014).

According to Moore and Calvert (2000), computer-based vocabulary lessons provide better motivation, attention, and vocabulary learning for children with ASD in comparison to lessons provided by a human instructor. Hetzroni and Tannous (2011) explored a computer-based intervention program aiming to improve the communicative abilities of children with ASD. The software program was 
constructed so as to comprise daily life activities about play, hygiene, and food. Research revealed that the program succeeded in enhancing communication and that children were able to adapt these improvements to the classroom environment (Hetzroni \& Tannous, 2011). Leonard et al. (2002) developed a single-user virtual reality environment that recreates real-life scenarios such as finding a place to sit in various settings. Adolescents with high functioning autism exhibited a significant enhancement in managing social scenarios appropriately (Leonard et al., 2002). Golan et al. (2010) evaluated an educational animated series named "The Transporters" developed by the Autism Research Centre. The Transporters consisted of toy vehicles running on tracks or cables (e.g. trams, cable cars) to restrain movement possibilities to simplify variables. Into the vehicles were inserted reallife faces of actors expressing emotions in a social context between the toy vehicles. By depicting social interactions between emotionally expressive toy vehicles, The Transporters aims to improve the emotion recognition ability of children with ASD. After the children watching The Transporters every day for four weeks, Golan et al. (2010) observed that children with ASD significantly improved in emotion recognition. In another important study focusing in social deficits, Bernard-Opitz et al. (2001) presented different animated social problems on a computer screen and asked for solutions. Subsequently, training sessions were conducted. In the training sessions, a person explained the solutions of the problems, and then the solutions were demonstrated through animations. After the training sessions, Bernard-Opitz et al. (2001) observed a stable increase in the success of children with ASD in solving social problems.

Despite various advantages of computer-aided systems, researchers have also suggested that individuals with ASD could experience difficulties in generalizing knowledge obtained through computers to everyday life (Bernard-Opitz et al., 2001; Lord \& Bishop, 2010; Cabibihan et al., 2013). Additionally, researchers express concern about dependence on computer-aided systems and the possibility of isolation (Moore \& Taylor, 2000).

\section{METODOLOGY}

Cognitive impairments caused by Autism Spectrum Disorder (ASD) lead to certain design concerns for producing suitable human-computer interfaces. Visual sensory produces more reaction from children with ASD than any other sensory type (Milley \& Machalicek, 2012). Since children with ASD are identified as visual thinkers (Frauenberger, Good, \& Alcorn, 2012), visual aids are provided to ease communication and learning for children with ASD. Also, the design principles set for serious games are applied to the Theory of Mind tests that are adapted. These design principles contain: gradually increasing levels of difficulty, defining clear task goals, providing clear instructions, delivering feedback and rewards, ensuring repeatability and predictability of the game tasks, presenting smooth transitions, and minimalistic graphics (Bartoli et al., 2014; Whyte et al., 2015). The tests are organized to require less effort at first and become progressively challenging to enhance engagement and motivation. The task objectives are intended to be clear so that they may be followed easily. The instructions are intended to be clear and the text is supported via visuals for better comprehension of the goals. Alongside continuous feedback, rewards with visuals are presented to encourage children with ASD (Whyte et al., 2015). Moreover, game play is used to modify the tests to become enjoyable and engage the users. Game dynamics are integrated into Theory of Mind tests by giving stars and badges to users at the time of completion (Pratt \& Nunes, 2012).

Additionally, Lidwell et al.'s (2010) principles overlapping with the scope of the tests are followed. Since baby-faces are more appealing to children, the characters of the tests are designed to have similar features to a baby-face by making their eyes rounder and larger. The number of colors used in the screens is minimized as much as possible, so that the human eye can comprehend them at first glance. The screens are designed to be consistent in terms of their setting, theme, colors, flow, and elements, since consistent interfaces are more user- friendly and easier to focus on. The distinction between the figure and the background is well defined and stable for the figure to grasp the user's attention and be remembered more than the background. Iconic symbols are used to enable users to recognize, find, 
remember, and learn more easily. Performance load is decreased as much as possible to increase the possibility of achieving a task. Related elements are grouped via proximity, similarity, or uniformity to increase clarity. Figure images are designed to be as symmetric as possible to deliver a sense of stability, harmony, and balance, and to grasp more attention. Additionally, the status of the user during the game is made visible in all scenes to enhance usability. Practices and guidelines for graphical user interfaces and online surveys by Lal (2013) are implemented as well. The interface aims to provide feedback concerning actions of the user in a pleasant, predictable and common manner. Answers are randomized to prevent border answer bias. Progress bars are utilized for multiple page tests. Information about the number of tests is given before starting.

Moreover, Fletcher-Watson et al.'s (2016) principles of design for children with ASD are employed. Characters in the games are designed to look like children. A reward token system is utilized and there is no reaction in the case of a wrong answer. Furthermore, Pavlov's (2014) principles for user interface design for individuals with ASD are followed closely and listed below:

- Font and background are designed to be contrasting.

- Soft and mild colors are used.

- The text box is noticeably disconnected from other elements.

- Text is displayed in a single column.

- Simple graphics are utilized.

- Clear sans-serif fonts are used.

- The background is designed to be plain without any images.

- Transparent surfaces and text do not overlay.

- Pop-ups are not used.

- Navigation is simple and easy to understand.

- The interface informs the user about the current position on every screen.

- The screens do not contain too many elements.

- Instructions are brief.

Heuristics by Khowaja and Salim (2015) for evaluating interactive systems for children with ASD are utilized and listed as follows:

- The status of the system is made constantly visible at the bottom of the screens via circles representing the current status to inform users about the duration, context, and current condition of the activities. The status of the system is presented via suitable feedback (collecting stars) between sensible time intervals (end of each task).

- The system aims to be easily comprehensible by the user. The system uses words, phrases, and concepts familiar to the user. The conventions in the system are similar to every-day life and information is provided in an ordinary and rational way.

- Language used in the screens is plain and coherent to not distract the user by using different words for the same meaning or using a word for multiple meanings.

- Unrelated or infrequently needed information does not appear on the interface screens since it may be a distraction for children with ASD.

- Redo and undo options are added to the system in case of choices by error. The user can undo by tapping the left side of the screen and redo by tapping the right side of the screen.

- The system tries to prevent errors as much as possible by asking for confirmation before executing an action.

- The screen items are adequately large to ensure ease of reading and access by children with ASD. A future ambition of the system is to permit customizability of color, background, font, and size.

- The transitions on the screen are smooth and gradual in order to avoid dramatic changes so children with ASD could follow.

- Possible latency of an action (e.g. selection) is aimed to be avoided since keeping the attention

Submit Date: 10.01.2019, Acceptance Date: 25.03.2019, DOI NO: 10.7456/10902100/006 
of the children with ASD is challenging, and they could get frustrated quickly.

Before starting the theory of mind tests, eight instruction screens are presented in order to provide information about possible actions and the length of the process. Screens have the following texts respectively:

- Hello, I am Zimo. Let's play games together.

- First, I will give you some clues.

- In order to go forward you should touch this (showing right) side.

- In order to come back you should touch this (showing left) side.

- Tap on the picture that you want to choose.

- If you are certain of your decision tap again.

- Congratulations! You have made your choice.

- You are ready now. Let's play four games together. Tap to start.

Also, after the completion of a test the transition screen appears. The user should tap the screen to start the next game. When the user has finished all the tests, the final screen appears to notify them. Screens have the following texts respectively:

- Tap to continue with the next game.

- Congratulations! You have completed all the games.

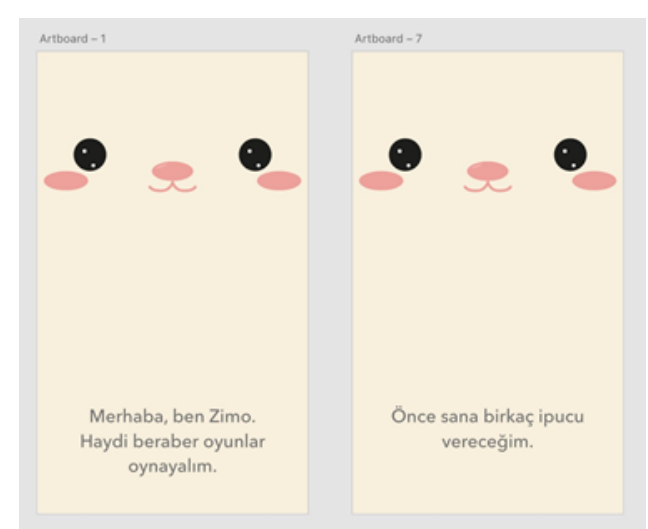

Figure 1. Instructions Sample, screens $1 \& 2$ 
Following the instruction screens, Theory of Mind tests are presented. Interfaces of the Theory of Mind tests that are adapted for the device are listed below:

1 - 'Inferring from gaze direction' test (Baron-Cohen \& Cross, 1992; Baron-Cohen et al., 1995)

Gaze direction allows normally developing children to understand which of the several objects a person wants. However, children with ASD are unable to retrieve that information as easily. The test of 'Which one does Charlie want?' reveals this difference between normally developing children and children with ASD. In the test, the child is presented the Figure 1 below, and asked the question: "Which one does Charlie want?" (Baron-Cohen \& Cross, 1992). The question is translated into Turkish as: "Çağrı hangisini istiyor?".

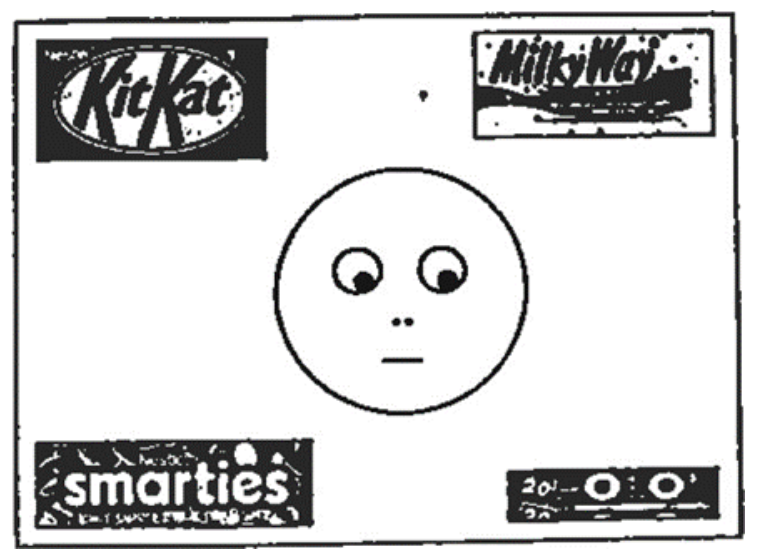

Figure 2. The test of "Which one does Charlie wants?", Baron-Cohen \& Cross, 1992

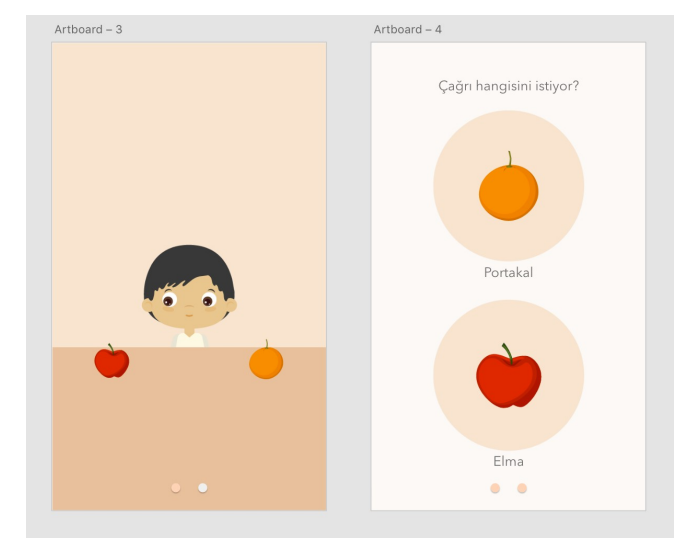

Figure 3. The 'inferring from gaze direction' test alternative visual design, screens $1 \& 2$

2- 'Seeing leads to knowing' test (Baron-Cohen \& Goodhart, 1994)

The 'Seeing leads to knowing' test by Baron-Cohen and Goodhart, (1994) contains a story about two characters. One of the characters investigates a box and the other one touches a box. Normally

Submit Date: 10.01.2019, Acceptance Date: 25.03.2019, DOI NO: 10.7456/10902100/006

Research Article - This article was checked by Turnitin

Copyright (C) The Turkish Online Journal of Design, Art and Communication 
developing 3-year-old children can comprehend who has the information about what is inside the box (Baron-Cohen \& Goodhart, 1994). On the other hand, children with ASD tend to choose a character arbitrarily, when they are asked, "Which one knows what is in the box?" (Baron- Cohen $\&$ Goodhart, 1994). The question is translated into Turkish as: "Kutunun içinde ne olduğunu hangisi biliyor?”.

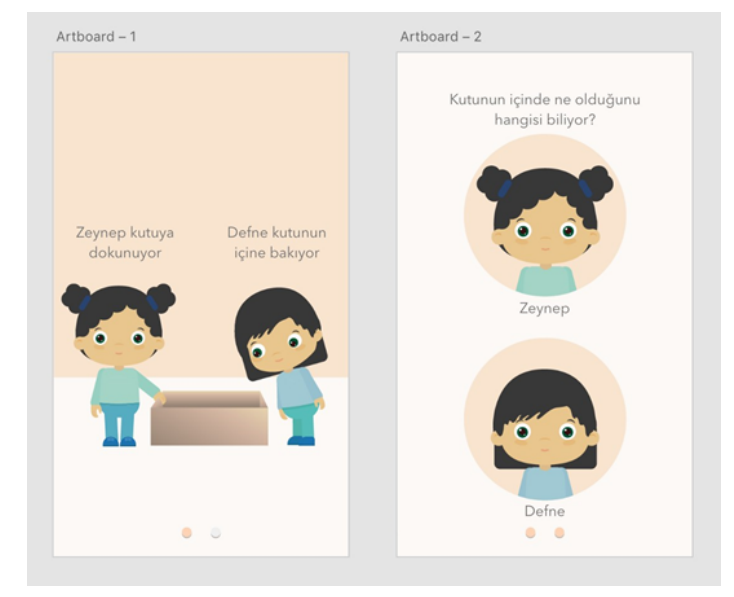

Figure 4. The 'seeing leads to knowing' test, screens $1 \& 2$

3- The mental-physical distinction (Baron-Cohen, 1989a)

The mental-physical distinction test Baron-Cohen (1989a) conducted comprises four stories; one of the stories is as follows:

"This is Sam. He likes biscuits. He is hungry, so his mother gives him a biscuit. This is Kate. She likes biscuits. She is hungry, but she is all alone. She is thinking about a biscuit." (Baron-Cohen, 1989a).

Subsequent to the story a behavioral judgment and a sensory judgment questions were asked, "Which child can eat the biscuit?" and "Which child can touch the biscuit?" correspondingly. (Baron-Cohen, 1989a). The story is adapted and translated into Turkish as following:

"Bu Selim. Selim bisküvi seviyor. Selim'in karnı aç. Bu yüzden annesi Selim'e bir bisküvi veriyor. Bu Cansu. Cansu bisküvi seviyor. Cansu'nun karnı aç, ama o yalnız başına. Bisküviyi düşünüyor.”

The questions that are asked following the story are translated as "Hangi çocuk bisküviyi yiyebilir?" and "Hangi çocuk bisküviye dokunabilir?" subsequently. 

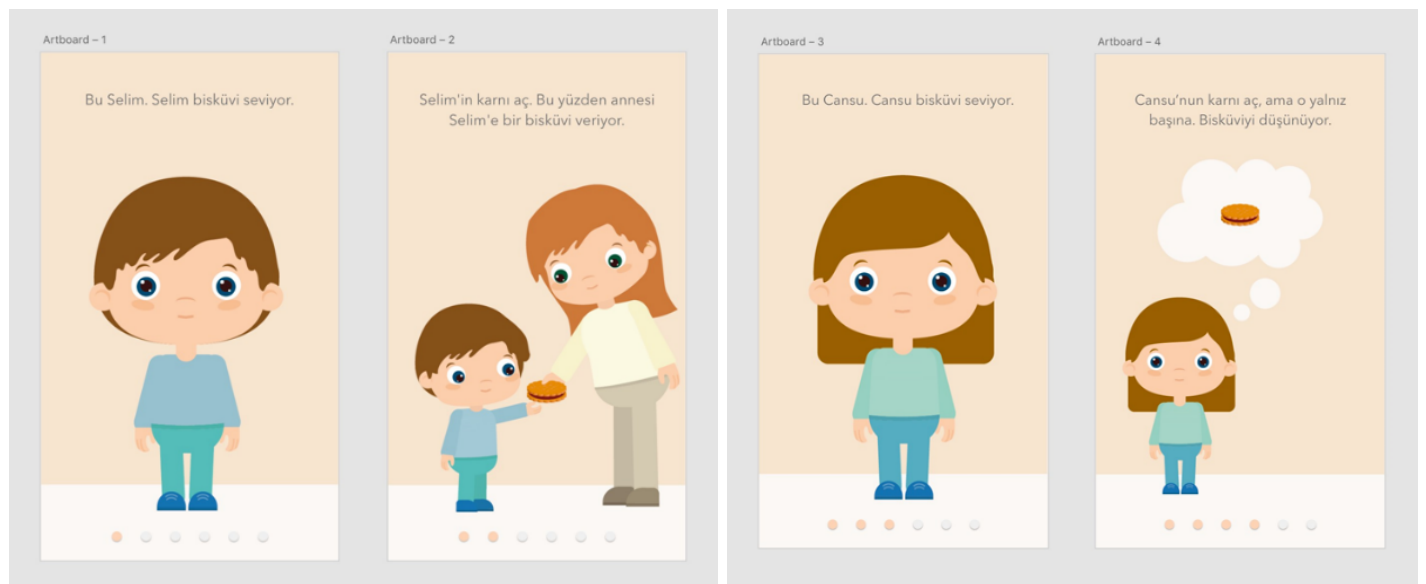

Figure 5. The 'mental-physical distinction test', screens 1,2,3,4

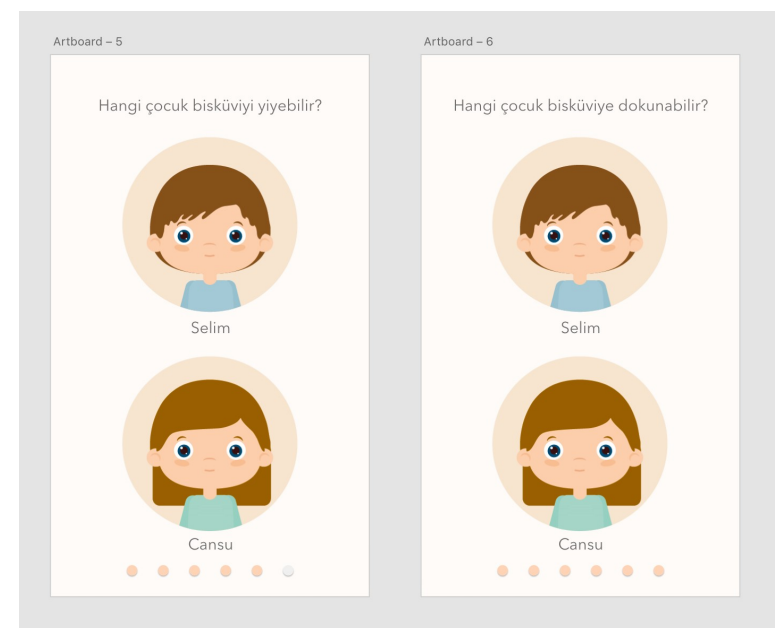

Figure 6. The 'mental-physical distinction' test, screens $5 \& 6$

4- First-order false belief task (Frith, 2001)

The Sally-Ann task is utilized as a first-order false belief task. In the Sally-Ann task the following story is enacted for the child:

"Sally has a basket and Anne has a box. Sally puts a marble into her basket, and then she goes out for a walk. While she is outside, naughty Anne takes the marble from the basket and puts it into her own box. Now Sally comes back from her walk and wants to play with her marble. Where will she look for the marble?" (Frith, 2001).

A normal developing 4-year-old child is expected to answer this question correctly, by giving an answer like "Sally will look inside her basket." However, children with ASD struggle with this task, even though they have a mental age of 4 years and above (Frith, 2001). The story is adapted and translated into Turkish as following:

“Selin'in bir sepeti ve Aslı'nın bir kutusu var. Selin sepetine bir top koyuyor ve sonra yürüyüş yapmak için dışarı çıkıyor. O dışarıdayken, yaramaz Aslı topu sepetten alıyor ve kendi kutusunun 
içine koyuyor. Şimdi Selin yürüyüşten dönüyor ve topuyla oynamak istiyor. Selin topu için nereye bakacak?"

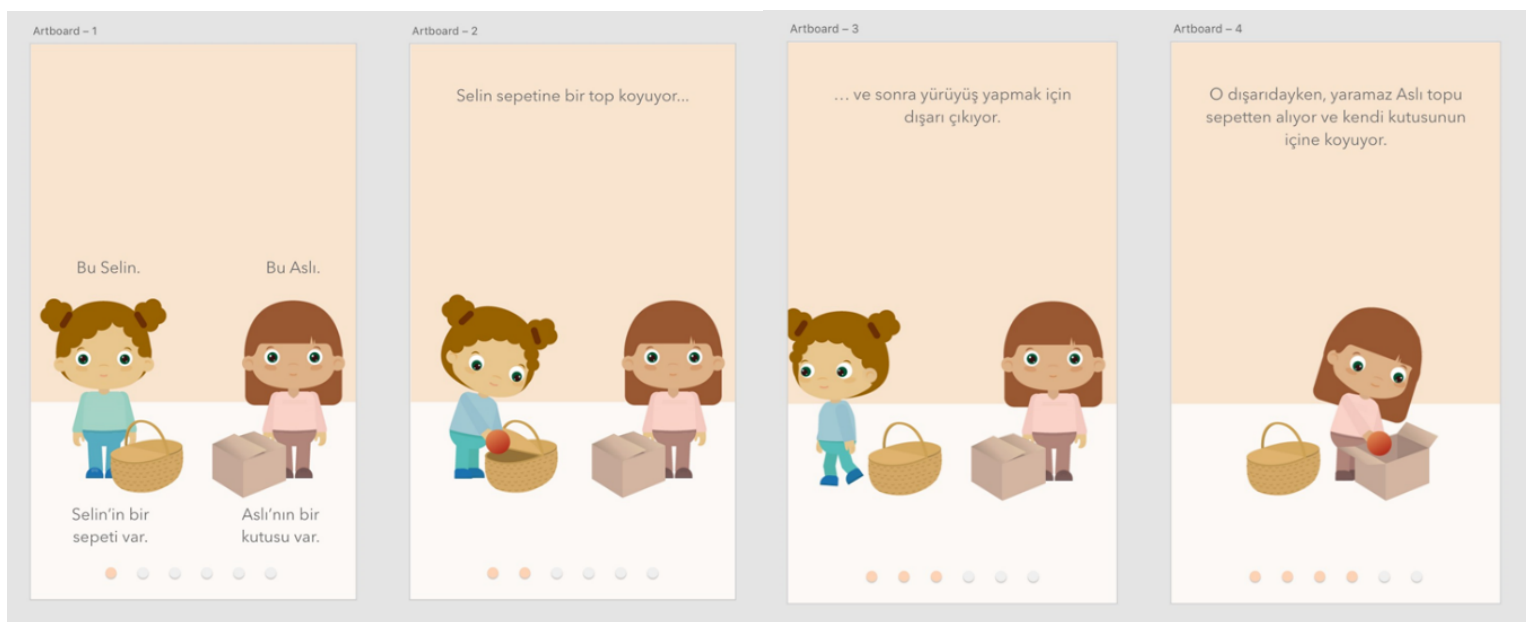

Figure 7. The Sally-Ann task, screens 1,2,3,4

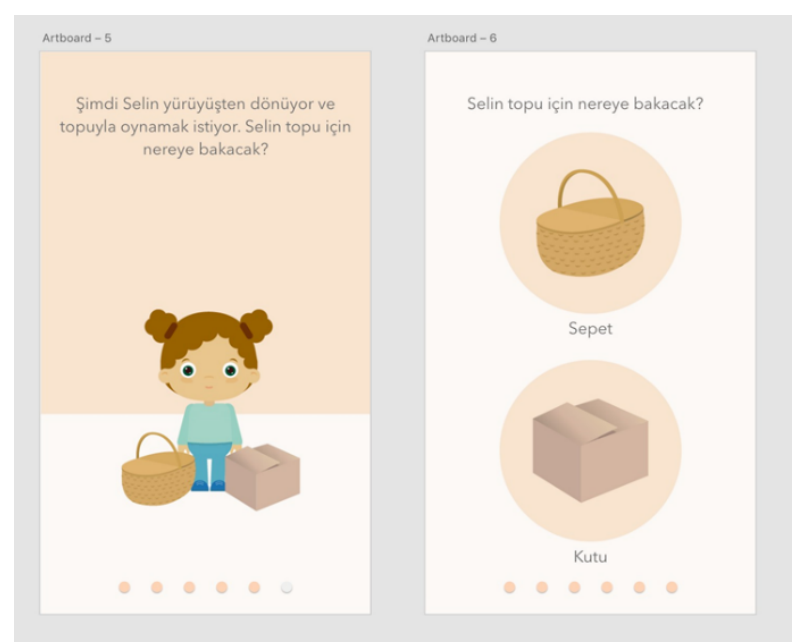

Figure 8. The Sally-Ann task, screens $5 \& 6$

\section{SHELL DESIGN OF THE PROTOTYPE}

Social robots are utilized for facilitating communication, expressing emotions, building social relationships, interpreting natural cues, enhancing social abilities, and diagnosis (Cabibihan et al., 2013). Social robots are used as a medium for diagnosis to elicit required behaviors for the diagnosis, gather and analyze data from behaviors of the child (Scassellati et al., 2012). By creating attractive and meaningful interactions, social robots can attract attention and engage with children (Cabibihan et al., 2013). Since social robots are precise, predictable and consistent children with autism are more interested in interacting with social robots than human agents (Pierno et al., 2008).

\section{Appearance of the Robotic Toy (Outer Shell)}

- The robot should be attractive to the child by appearance. The shell is designed to match a nonanthropomorphic appearance since designs that do not resemble humans evoke a more positive 
response (Robins et al., 2006), cartoon-like characters lead to more stimulation (Duquette et al., 2008; Michaud et al., 2003), and non-anthropomorphic designs received positive feedback from children with ASD (Robins et al., 2007). The appearance of the shell tends to be simple, easy to operate, and toy-like. Kozima et al. $(2007 ; 2009)$ showed that a very simple robot design (see Figure 9) could retain the attention of children with ASD and enable social interaction.
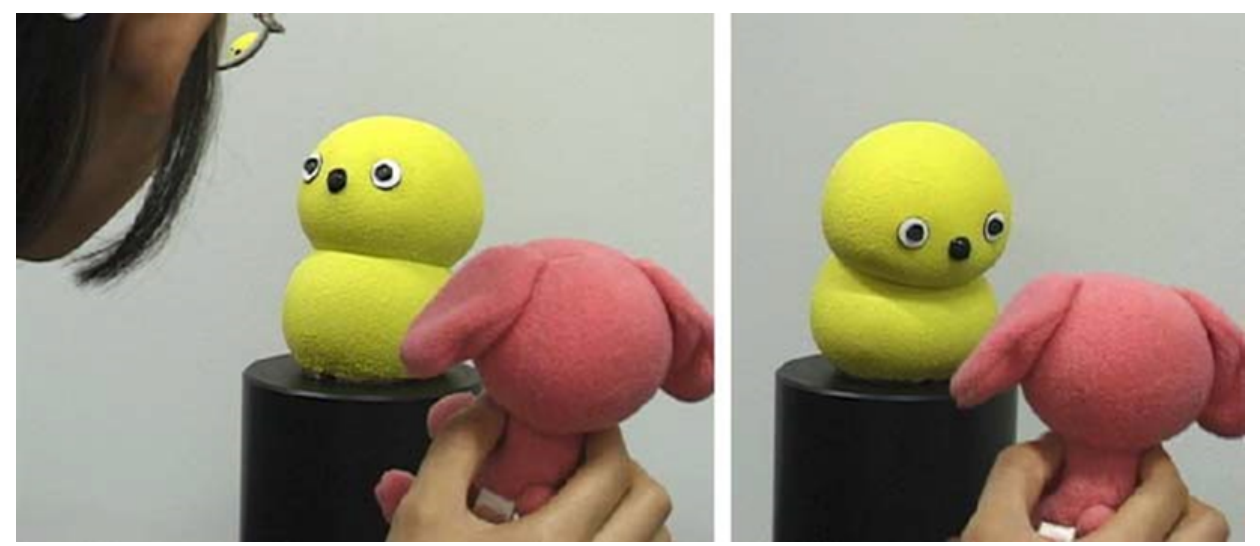

Figure 9. Keepon, interactive robot, Kozima et al., 2009

- On the front side of the robotic toy, A Raspberry Pi 7-inch microcomputer equipped with a single touchscreen display is placed vertically to enable interaction with the use of visual elements based on variety of tests and games. According to Hourcade et al, the visual interface attracts the participants' focus, thus facilitates a more structured content for the interaction scenarios, rather than the ongoing ambiguity during a social interaction and consequently could result in a reduction of the anxiety. During the use of touchscreen technologies, children with ASD are observed to be actively involved and verbal during the observations (Hourcade et al., 2012).

- The outer shell is designed to be simple and appealing. By following Pavlov's (2014) principle of using soft and mild colors, color of the outer shell is chosen to be light beige to eliminate redundant stimuli and reduce distraction. Because according to Pavlov's observations (2014), participants tend to perform poorer on richer multimedia interfaces. Users have a difficulty in organizing multimodal sources of information. The finalized version (see Figure 10) is designed to enable being carried by being held under the arms, which are curved inwards so that the hands may be placed conveniently. The bottom side of the outer shell design is leveled to be balanced when it is placed on a table. The front side of the shell is tilted so that the participant can be able to see the screen at a more convenient angle, while sitting on a chair. Size and weight of the device are considered not to exceed the limits to be carried by caregivers, therapists, and the child. 


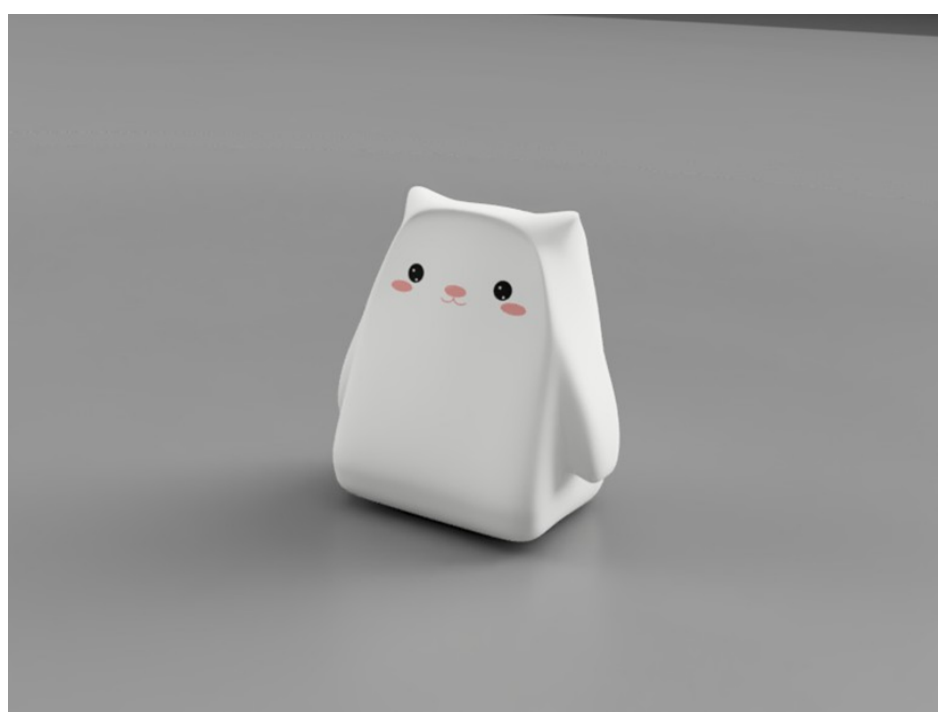

Figure 10. Final drawings of the outer shell design

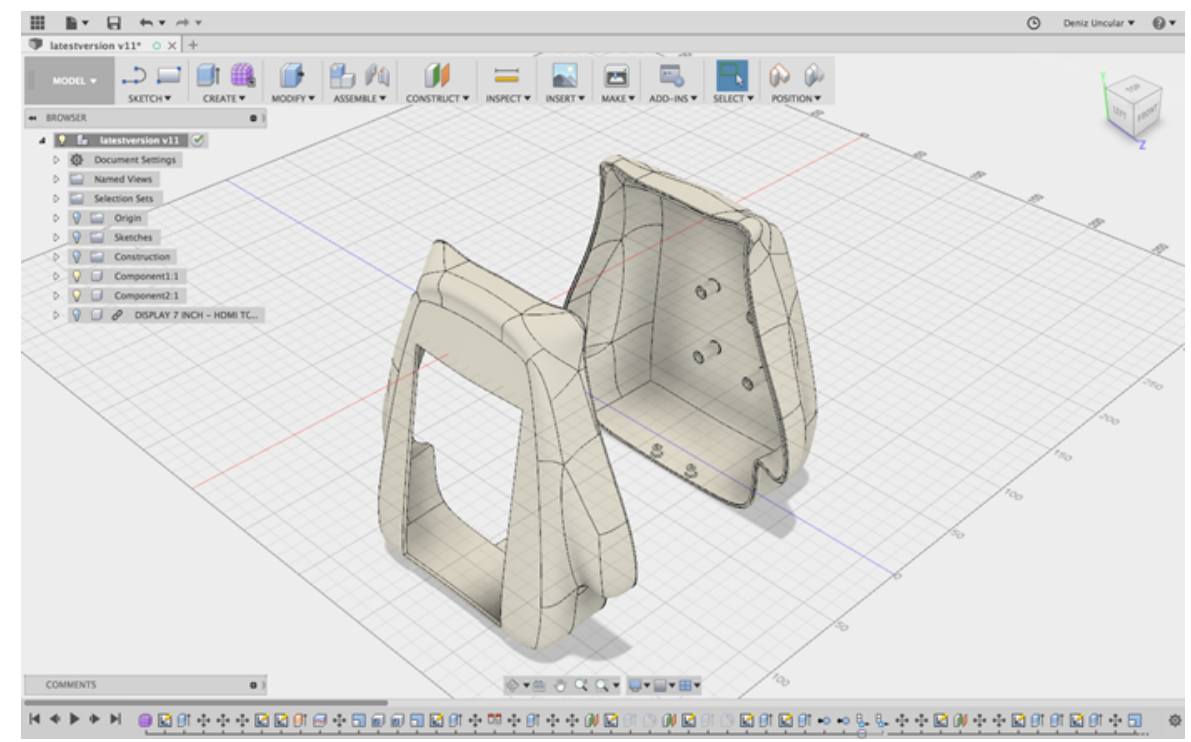

Figure 11. Components in Autodesk Fusion 360, front

Finally, outer shell prototype is 3D printed by Raise3D N2 Plus FFF 3D Printer at Collaboration Space, Sabanci University. 3D printing is preferred as the production method due to its numerous advantages over machining and casting methods. 3D printing enables direct production of functional parts in small numbers. Despite 3D printed parts usually have a lower accuracy and surface finish compared to parts produced by machining; some sophisticated systems can create high quality parts close to machining quality. 3D printing is advantageous particularly in production times; it can significantly shorten production times, which can be only several hours (Chua \& Leong, 2014). Another significant advantage of 3D printing is providing the opportunity to experiment with complex physical models in comparatively brief time. According to Chua and Leong (2014), 3D printing can reduce the cost and time spent by $50 \%$ to $90 \%$ depending on the production scale when it is compared to CAD-CAM and computer numerical control (CNC) technologies. Due to its ability to produce more organic and complex forms, it enables designs to be more useful and appealing. Also, 3D printing can reduce the amount of parts produced by being 
able to merge the parts and produce them as a single part. On the other hand, machining imposes parts to be produced separately to reduce waste and machining cost (Chua \& Leong, 2014). By decreasing the amount of parts produced, time spent on tolerance analysis and detailed assembly drawings are reduced. Moreover, design constraints (e.g. avoiding draft angles, thin walls, and complex shapes) due to machining limitations are eliminated by 3D printing. Finally, fixed costs are lower, part specific setting up and programming is not required, machining or casting labor is decreased, material waste is reduced, unit price nearly becomes independent of production quantity (Chua \& Leong, 2014).

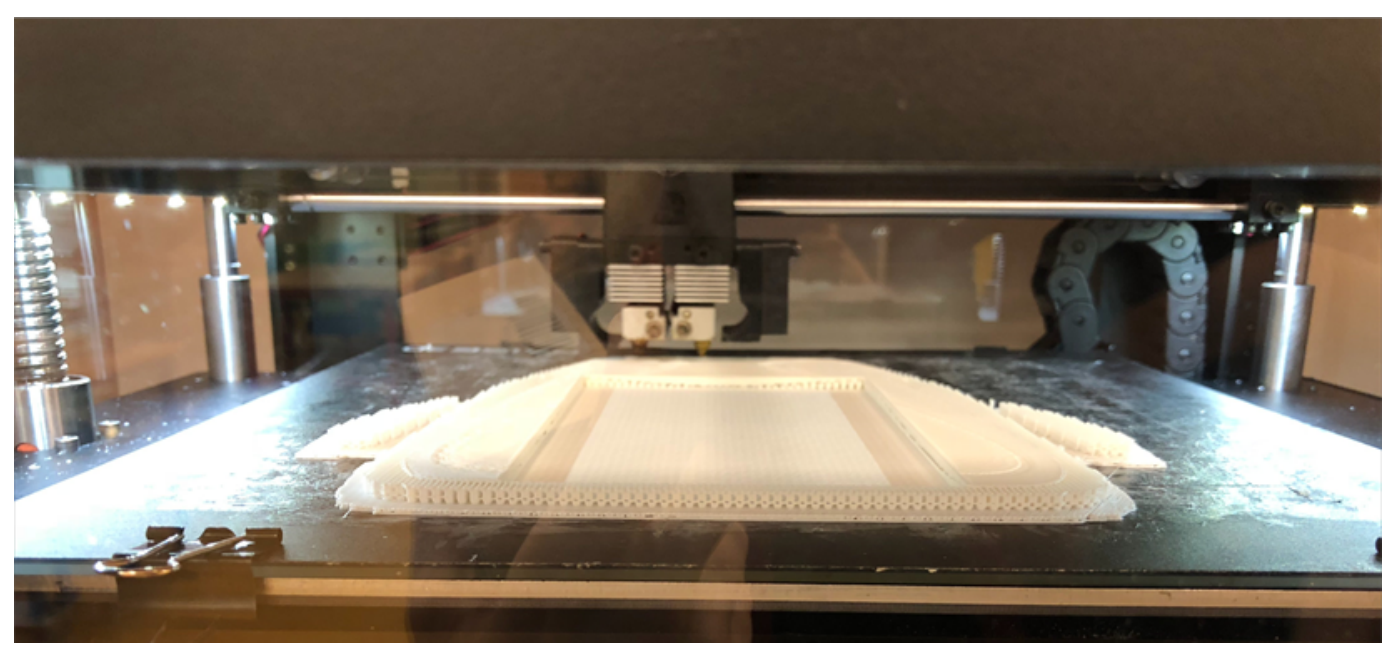

Figure 12. 3D printing process of the shell, front

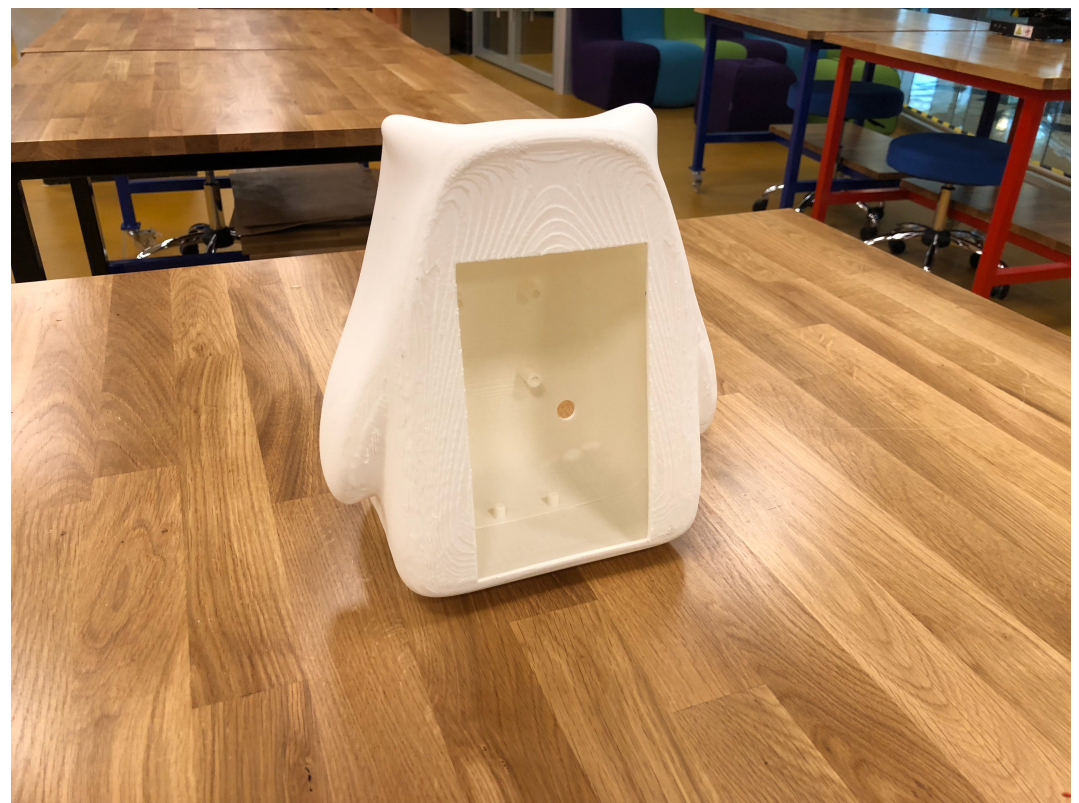

Figure 13. The attached state of the 3D printed components, front 


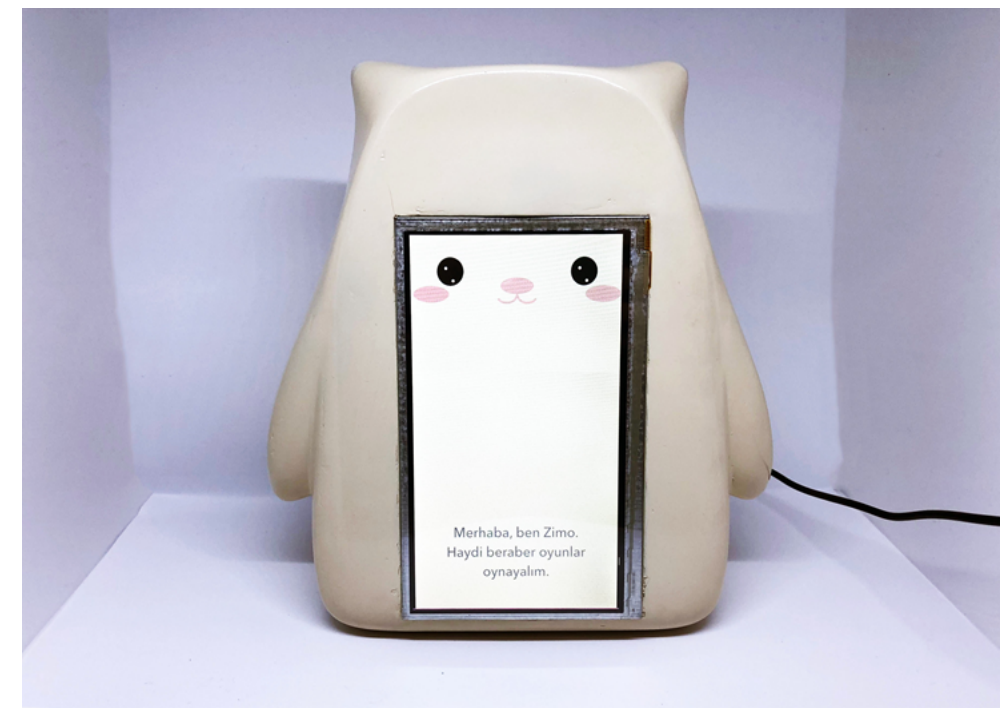

Figure 14. Prototype displaying the opening screen

\section{DISCUSSION}

Future implementations for the project include; adding a rechargeable battery unity to provide an option to move the device independently, adding a build-in speaker to provide background music and sound effects, adding LEDs to increase interactivity (child could be given the option to choose the type of sensory rewards from light, audio, and visual), being in communication with external physical objects, providing camera interactions, adding various biosensors (e.g. pulse sensor, ultrasonic sensor, and motion sensor), enabling the use of eye-tracking technologies, and collecting extended data (demographics, time spent to give an answer, heart rate, gaze direction...) from participants. Another future ambition of this thesis is making the robotic toy a home- based device so that assessment can be made in the natural environment of the child (Rakap et al., 2017), since gathering data independent of the clinic environment improves the quantity and quality of the data (Scassellati, 2005). Also, a parent questionnaire can be added to gather more data about the child. A training phase can be added to provide the child more time to be accustomed to the software.

Since, abnormal visual scanning pattern is a substantial sign of ASD (Senju et al., 2003) enabling the use of eye-tracking technologies would provide significant data for the research. Perphery et al. (2002) revealed that individuals with ASD spent significantly more time observing the outer features of the face, and spent less time viewing the inner (primary) features such as the nose, mouth, and especially the eyes when compared with individuals without ASD. According to Riby and Hancock (2008) when presented static images of socially interacting individuals, individuals with ASD spend less time looking at faces and spend more time looking at background or body areas compared to typically developed individuals. Another study by Riby and Hancock (2009) revealed abnormal gaze patterns were present for all stimuli types (containing human actor and cartoon images or movies). Besides these abnormal processing strategies resulted from ASD, cultural differences considered to be an influential factor for societies in terms of their visual strategies (Masuda et. al, 2008). Eye tracking has established to be beneficial for revealing the attributes of abnormal visual scanning patterns in ASD. Riby and Hancock $(2008 ; 2009)$ utilized a Tobii 1750 eye-tracker to record eye movements in their studies. Another future implementation of the project would be to record eye movements during social scene parsing by connecting a Tobii 1750 eye-tracker to the device and analyzing gaze pattern data considering cultural differences.

\section{CONCLUSION}

Exploring the effective implementations of convenient technological opportunities in use of assistive technologies enhances our research abilities to convey existing information to further investigations. This study aims to build a prototype of a robotic toy to structure a basis for 
scrutinizing the ASD with its possible technological resolutions. Although there are serious limitations to rationalize the observations to a list of solidified facts and figures, there has been a considerable amount of research accomplished compassing the field. It has been observed that individuals with ASD tend to perform worse when identifying the five basic emotions (anger, disgust, happiness, sadness, and surprise) than the control group even they were statistically equivalent and performed statistically poorer in identifying fear. Differences in face scanning strategies from typically developed individuals may be the core reason for the poor face perception and emotion recognition abilities among individuals with ASD (Perphery et al., 2002). Thus, this study explores finding interactive platforms to explore the ways of configuring such systems to point out relevant inadequacies. With reference to the basics of the already practiced diagnosis tests, the authors of this research aim to revitalize the visual elements of the content with appealing designs in line with the suggested research concerns. The proposed robotic toy "Zimo" with its 3D body stands as a charming platform for its recipients thus enables researchers to carry out diversified analysis on the topic of ASD with relatively seamless interventions. Additionally, the extensible technological structure of the Zimo and its comparably low-costs enable the researchers to further implement additional enhancements into the system comfortably.

\section{REFERENCES}

Aksoy, V., \& Diken, İ. H. (2017). Otizm spektrum bozukluğu gösteren çocuklar için eğitsel değerlendirme ve ögrrenme hızı öngörüsü kayıt formlarının psikometrik niteliklerinin belirlenmesi. Ilkögretim Online, 16(1).

American Psychiatric Association. (2013). Diagnostic and statistical manual of mental disorders (DSM-5®). American Psychiatric Pub.

Baio, J. (2014). Developmental Disabilities Monitoring Network Surveillance Year 2010 Principal Investigators; Centers for Disease Control and Prevention (CDC). Prevalence of autism spectrum disorder among children aged 8 years-Autism and developmental disabilities monitoring network, 11 sites, United States, 2010. MMWR Surveill. Summ, 63, 1-21.

Baldwin, D. A., Markman, E. M., Bill, B., Desjardins, R. N., Irwin, J. M., \& Tidball, G. (1996). Infants' reliance on a social criterion for establishing word-object relations. Child development, 67(6), 3135-3153.

Baron-Cohen, S. (1989). Are autistic children "behaviorists"? An examination of their mentalphysical and appearance-reality distinctions. Journal of autism and developmental disorders, 19(4), 579-600.

Baron Cohen, S., \& Cross, P. (1992). Reading the eyes: evidence for the role of perception in the development of a theory of mind. Mind \& Language, 7(1-2), 172- 186.,

Baron Cohen, S., \& Goodhart, F. (1994). The 'seeing-leads-to-knowing'deficit in autism: The Pratt and Bryant probe. British Journal of Developmental Psychology, 12(3), 397-401.

Baron-Cohen, S., Campbell, R., Karmiloff-Smith, A., Grant, J., \& Walker, J. (1995). Are children with autism blind to the mentalistic significance of the eyes?. British Journal of Developmental Psychology, 13(4), 379-398.

Bartoli, L., Garzotto, F., Gelsomini, M., Oliveto, L., \& Valoriani, M. (2014). Designing and evaluating touchless playful interaction for ASD children.

Bates, E., Benigni, L., Bretherton, I., Camaioni, L., \& Volterra, V. (1979). The emergence of symbols: Communication and cognition in infancy. New York: Academic.

Bernard-Opitz, V., Sriram, N., \& Nakhoda-Sapuan, S. (2001). Enhancing social problem solving in children with autism and normal children through computer-assisted instruction. Journal of autism and developmental disorders, 31(4), 377-384.

Bloom, P. (2000). How children learn the meanings of words. The MIT Press.

Boucenna, S., Narzisi, A., Tilmont, E., Muratori, F., Pioggia, G., Cohen, D., \& Chetouani, M. (2014). Interactive technologies for autistic children: A review. Cognitive Computation, 6(4), 722-740. 
Bretherton, I. (1992). Social referencing, intentional communication, and the interfacing of minds in infancy. In Social referencing and the social construction of reality in infancy (pp. 57-77). Springer US.

Cabibihan, J. J., Javed, H., Ang, M., \& Aljunied, S. M. (2013). Why robots? A survey on the roles and benefits of social robots in the therapy of children with autism. International journal of social robotics, 5(4), 593-618.

Carpenter, M., Nagell, K., Tomasello, M., Butterworth, G., \& Moore, C. (1998). Social cognition, joint attention, and communicative competence from 9 to 15 months of age. Monographs of the society for research in child development, $i-174$.

Chua, C. K., \& Leong, K. F. (2014). 3D Printing and Additive Manufacturing: Principles and Applications (with Companion Media Pack) of Rapid Prototyping Fourth Edition. World Scientific Publishing Company.

Dahlgren, S. O., \& Gillberg, C. (1989). Symptoms in the first two years of life. European archives of psychiatry and neurological sciences, 238(3), 169-174.

Dautenhahn, K. (2003). Roles and functions of robots in human society: implications from research in autism therapy. Robotica, 21(4), 443-452.

Dawson, G., Osterling, J., Meltzoff, A. N., \& Kuhl, P. (2000). Case study of the development of an infant with autism from birth to two years of age. Journal of Applied Developmental Psychology, 21(3), 299-313.

De Giacomo, A., \& Fombonne, E. (1998). Parental recognition of developmental abnormalities in autism. European child \& adolescent psychiatry, 7(3), 131-136.

Duquette, A., Michaud, F., \& Mercier, H. (2008). Exploring the use of a mobile robot as an imitation agent with children with low-functioning autism. Autonomous Robots, 24(2), 147-157.

Feil-Seifer, D., \& Mataric, M. J. (2005). Defining socially assistive robotics. In Rehabilitation Robotics, 2005. ICORR 2005. 9th International Conference on (pp. 465-468). IEEE.

Fletcher-Watson, S., Pain, H., Hammond, S., Humphry, A., \& McConachie, H. (2016). Designing for young children with autism spectrum disorder: a case study of an iPad app. International Journal of Child-Computer Interaction, 7, 1-14.

Frauenberger, C., Good, J., \& Alcorn, A. (2012). Challenges, opportunities and future perspectives in including children with disabilities in the design of interactive technology. In Proceedings of the 11th International Conference on Interaction Design and Children (pp. 367-370). ACM.

Frith, U. (2001). Mind blindness and the brain in autism. Neuron, 32(6), 969-979.

Golan, O., Ashwin, E., Granader, Y., McClintock, S., Day, K., Leggett, V., \& Baron-Cohen, S. (2010). Enhancing emotion recognition in children with autism spectrum conditions: An intervention using animated vehicles with real emotional faces. Journal of autism and developmental disorders, 40(3), 269-279.

Goodwin, M. S. (2008). Enhancing and accelerating the pace of autism research and treatment: The promise of developing innovative technology. Focus on autism and other developmental disabilities, 23(2), 125-128.

Goodwin, M. S., Groden, J., Velicer, W. F., Lipsitt, L. P., Baron, M. G., Hofmann, S. G., \& Groden, G. (2006). Cardiovascular arousal in individuals with autism. Focus on autism and other developmental disabilities, 21(2), 100-123.

Grynszpan, O., Martin, J. C., \& Nadel, J. (2008). Multimedia interfaces for users with high functioning autism: An empirical investigation. International Journal of Human-Computer Studies, 66(8), 628-639.

Hetzroni, O. E., \& Tannous, J. (2004). Effects of a computer-based intervention program on the communicative functions of children with autism. Journal of autism and developmental disorders, 34(2), 95-113.

Hourcade, J. P., Bullock-Rest, N. E., \& Hansen, T. E. (2012). Multitouch tablet applications and activities to enhance the social skills of children with autism spectrum disorders. Personal and ubiquitous computing, 16(2), 157-168. 
Hoshino, Y., Kumashiro, H., Yashima, Y., Tachibana, R., Watanabe, M., \& Furukawa, H. (1982). Early symptoms of autistic children and its diagnostic significance. Psychiatry and Clinical Neurosciences, 36(4), 367-374.

Khowaja, K., \& Salim, S. S. (2015). Heuristics to evaluate interactive systems for children with Autism Spectrum Disorder (ASD). PloS one, 10(7), e0132187.

Kozima, H., Nakagawa, C., \& Yasuda, Y. (2007). Children-robot interaction: a pilot study in autism therapy. Progress in Brain Research, 164, 385-400.

Kozima, H., Michalowski, M. P., \& Nakagawa, C. (2009). Keepon. International Journal of Social Robotics, 1(1), 3-18.

Lal, R. (2013). Digital Design Essentials: 100 ways to design better desktop, web, and mobile interfaces. Design Essentials.

Leonard, A., Mitchell, P., \& Parsons, S. (2002). Finding a place to sit: a preliminary investigation into the effectiveness of virtual environments for social skills training for people with autistic spectrum disorders. Virtual Reality and Associated Technologies, Veszprem, Hungary, University of Reading.

Lidwell, W., Holden, K., \& Butler, J. (2010). Universal principles of design, revised and updated: 125 ways to enhance usability, influence perception, increase appeal, make better design decisions, and teach through design. Rockport Pub.

Lord, C., \& Bishop, S. L. (2010). Autism Spectrum Disorders: Diagnosis, Prevalence, and Services for Children and Families. Social Policy Report. Volume 24, Number 2. Society for Research in Child Development.

Maestro, S., Muratori, F., Cavallaro, M. C., Pei, F., Stern, D., Golse, B., \& Palacio- Espasa, F. (2002). Attentional skills during the first 6 months of age in autism spectrum disorder. Journal of the American Academy of Child \& Adolescent Psychiatry, 41(10), 1239-1245.

Masuda, T., Ellsworth, P. C., Mesquita, B., Leu, J., Tanida, S., \& Van de Veerdonk, E. (2008). Placing the face in context: Cultural differences in the perception of facial emotion. Journal of Personality and Social Psychology, 94, 365-381. doi:10.1037/0022-3514.94.3.365

Meltzoff, A. N. (1995). Understanding the intentions of others: Re-enactment of intended acts by 18-month-old children. Developmental psychology, 31(5), 838.

Michaud, F., Duquette, A., \& Nadeau, I. (2003). Characteristics of mobile robotic toys for children with pervasive developmental disorders. In Systems, Man and Cybernetics, 2003. IEEE International Conference on (Vol. 3, pp. 2938-2943). IEEE.

Milley, A., \& Machalicek, W. (2012). Decreasing students' reliance on adults: A strategic guide for teachers of students with autism spectrum disorders. Intervention in School and Clinic, 48(2), 6775 .

Moore, M., \& Calvert, S. (2000). Brief report: Vocabulary acquisition for children with autism: Teacher or computer instruction. Journal of autism and developmental disorders, 30(4), 359-362.

Moore, D., \& Taylor, J. (2000). Interactive multimedia systems for students with autism. Journal of Educational Media, 25(3), 169-177.

Ornitz, E. M., Guthrie, D., \& Farley, A. H. (1977). The early development of autistic children. Journal of Autism and Developmental Disorders, 7(3), 207-229.

Osterling, J., \& Dawson, G. (1994). Early recognition of children with autism: A study of first birthday home videotapes. Journal of autism and developmental disorders, 24(3), 247-257.

Pavlov, N. (2014). User interface for people with autism spectrum disorders. Journal of Software Engineering and Applications, 7(02), 128.

Pelphrey, K. A., Sasson, N. J., Reznick, J. S., Paul, G., Goldman, B. D., \& Piven, J. (2002). Visual scanning of faces in autism. Journal of autism and developmental disorders, 32(4), 249-261.

Pierno, A. C., Mari, M., Lusher, D., \& Castiello, U. (2008). Robotic movement elicits visuomotor priming in children with autism. Neuropsychologia, 46(2), 448- 454.

Pratt, A., \& Nunes, J. (2012). Interactive design: An introduction to the theory and application of user-centered design. Rockport Pub.

Rakap, S., Birkan, B., and Kalkan, S. (2017). Türkiye'de otizm spectrum bozukluğu ve özel eğitim. Tohum Otizm Vakfi. 
Repacholi, B. M. (1998). Infants' use of attentional cues to identify the referent of another person's emotional expression. Developmental psychology, 34(5), 1017.

Riby, D. M., \& Hancock, P. J. (2009). Do faces capture the attention of individuals with Williams syndrome or autism? Evidence from tracking eye movements. Journal of autism and developmental disorders, 39(3), 421-431.

Robins, B., Dautenhahn, K., \& Dubowski, J. (2006). Does appearance matter in the interaction of children with autism with a humanoid robot?. Interaction studies, 7(3), 479-512.

Robins, B., Otero, N., Ferrari, E., \& Dautenhahn, K. (2007). Eliciting requirements for a robotic toy for children with autism-results from user panels. In Robot and Human interactive Communication, 2007. RO-MAN 2007. The 16th IEEE International Symposium on (pp. 101-106). IEEE.

Scassellati, B., Admoni, H., \& Matarić, M. (2012). Robots for use in autism research. Annual review of biomedical engineering, 14, 275-294.

Senju, A., Yaguchi, K., Tojo, Y., \& Hasegawa, T. (2003). Eye contact does not facilitate detection in children with autism. Cognition, 89(1), B43-B51.

Türkiye'deki Bireylerin Otizm Algısı ve Bilgi Düzeyi Araştırması. (2017). Retrieved February 20, 2018, from http://www.tohumotizm.org.tr/yayin/turkiyedeki-bireylerin-otizm-algisi-ve-bilgi-duzeyiarastirmasi-2017

Volkmar, F. R., Klin, A., Siegel, B., Szatmari, P., Lord, C., Campbell, M., ... \& Buitelaar, J. (1994).

Field trial for autistic disorder in DSM-IV. The American journal of psychiatry.

Werner, E., Dawson, G., Osterling, J., \& Dinno, N. (2000). Brief report: Recognition of autism spectrum disorder before one year of age: A retrospective study based on home videotapes. Journal of autism and developmental disorders, 30(2), 157-162.

Whyte, E. M., Smyth, J. M., \& Scherf, K. S. (2015). Designing serious game interventions for individuals with autism. Journal of autism and developmental disorders, 45(12), 3820-3831.

Wimpory, D. C., Hobson, R. P., Williams, J. M. G., \& Nash, S. (2000). Are infants with autism socially engaged? A study of recent retrospective parental reports. Journal of Autism and Developmental Disorders, 30(6), 525-536. 